\title{
Decomposition and Nutrient Release of Tree Legumes in an Agroforest System
}

\author{
Larissa Brandão Portela ${ }^{1}$, Anágila Janenis Cardoso Silva ${ }^{1}$, Gustavo André de Araújo Santos ${ }^{2}$, \\ Joab Luhan Ferreira Pedrosa ${ }^{3}$, Conceição de Maria Batista de Oliveira ${ }^{3} \&$ Alana das Chagas Ferreira Aguiar ${ }^{1}$ \\ ${ }^{1}$ Universidade Federal do Maranhão, São Luís, Maranhão, Brazil \\ ${ }^{2}$ Universidade Estadual Paulista, Jaboticabal, São Paulo, Brazil \\ ${ }^{3}$ Universidade Federal do Espírito Santo, Alegre, Espírito Santo, Brazil \\ Correspondence: Larissa Brandão Portela, Universidade Federal do Maranhão, 65080-805, São Luís, Maranhão, \\ Brazil. Tel: 55-98-982-905-432. E-mail: lbportela@hotmail.com
}

Received: February 24, 2018

Accepted: June 2, $2018 \quad$ Online Published: July 15, 2018

doi:10.5539/jas.v10n8p417

URL: https://doi.org/10.5539/jas.v10n8p417

\begin{abstract}
The research compared biomass production and nutrient release in an alley cropping system in two collection methods, the litterbag method and the direct collection method (Morley, Bennett, \& Clark, 1964). The system was implemented in 2015 at 2017, at the Maranhão Federal University, Maranhão, Brazil. The experiment was a randomized block design with four treatments, consisting of leucaena+sombreiro (Leucaena leucocephala and Clitoria fairchildiana), leucena+acacia (Leucaena leucocephala and Acacia mangium), gliricidia+sombreiro (Gliricidia sepium and Clitoria fairchildiana) and gliricidia+acacia (Gliricidia sepium and Acacia mangium). In order to determine the remaining dry matter, nutrient release $(\mathrm{N}, \mathrm{P}, \mathrm{K}, \mathrm{Ca}, \mathrm{Mg}$ and $\mathrm{Mn})$, the decomposition constants and the half-lives times of plant residues, $100 \mathrm{~g}$ of fresh material were conditioned in litterbags $(50 \mathrm{~g}$ of each species), arranged on the soil surface. The second method was done by randomly throwing a collector on each plot in the same dimensions of the litterbags $(0.40 \times 0.40 \mathrm{~m})$ and collecting the litter. For the two methods samples were collected at $0,30,60,90$ and 120 days after the start of the experiment. The litterbags method showed a higher $\mathrm{C} / \mathrm{N}$ ratio at day 30 up to 120 days, which implies that this method is providing a different environment from the litter, where it would be overestimating the $\mathrm{C} / \mathrm{N}$ ratio and retarding the decomposition. The $\mathrm{G}+\mathrm{S}$ and $\mathrm{G}+\mathrm{A}$ combinations were more rapidly decomposed than the combinations of $\mathrm{L}+\mathrm{S}$ and $\mathrm{L}+\mathrm{A}$. The following order of release was established for the litterbags method: $\mathrm{P}>\mathrm{N}>\mathrm{K}>\mathrm{Ca}>\mathrm{Mn}>\mathrm{Mg}$, and for the method of collecting the litter: $\mathrm{N}>\mathrm{P}>\mathrm{Ca}>\mathrm{Mg}>\mathrm{K}>\mathrm{Mn}$.
\end{abstract}

Keywords: nutrient cycling; litter; system alleys, humid tropics

\section{Introduction}

The litterbags method is the most used to determine the rates of decomposition of biomass applied in an agroforestry system, which allows experimental decomposition tests under field conditions. In this method, a known amount of tree biomass is placed in bags with suitable mesh sizes and then deposited on the soil surface. A large number of litterbags are installed at the beginning of the experiment, and collected periodically over time. The decomposition rates are determined from the mass loss placed on the litterbag. It consists of a simple and inexpensive method, widely used in bioassays (Hobbie \& Gough, 2004).

In addition to this, a great advantage of the method is that the estimation of the decomposition rate from litterbags is based on the fact that the remaining material, besides providing data to make the "decomposition curves", also allows the analysis of the release of nutrients over time. However, this method has some limitations. The size of the mesh can exclude important decomposing organisms. In contrast, litterbags with mesh containing large holes can promote large losses of the contents, besides allowing the entrance of materials that were not considered in the installation of the experiment (Andrade, Caballero, \& Faria, 1999), such as leaflets, weeds or small particles of ground. Another technical and methodological impasse related to the use of litterbags consists in the quantification of the decomposition constant (k), which only takes into account the leaf fraction and fine branches to the detriment of the other fractions that compose the vegetal biomass deposited in the soil. 
Another limitation derives from the failure to consider the destination of the lost litter, as well as not counting the interaction potential between the different components of the litter over time, with overestimation or underestimation of the nutrient contents released by the litterbags. Thus, it is clear that there are possible systematic differences between the two methods due to differences in the exposure of the sample surface and/or contact with the existing litter. Since few researches have compared the two methods simultaneously to determine the release of nutrients, the objective of this work was to compare the release of nutrients between litterbags method with a method of direct collection of litter in an alley crop system.

\section{Material and Methods}

The experiment was developed in the years of 2015 to 2017. The local relief characterizes as a region of low plateau with vegetation of fields and enclosed covering flat relief. The experimental area was previously occupied by native secondary vegetation. The region of the study area is under humid tropical climate, has an average temperature of $29^{\circ} \mathrm{C}$, maximum of $37^{\circ} \mathrm{C}$ and altitude of 110 meters above sea level. The rainy season is diverse between November and May.

The tree legumes were sown in January 2012, in rows spaced $2.0 \mathrm{~m}$ between rows and $0.5 \mathrm{~m}$ between plants. Two tree species with high quality of residues were used: leucena and gliricidia (Leucaena leucocephala and Gliricidia sepium), and two low quality tree species: shade and acacia (Clitoria fairchildiana and Acacia mangium), combined in rows so that each plot received the two residues simultaneously. The soil of the area was classified as Distortic Quartzite. Based on pre-planting soil analysis (Table 1), the entire experimental area was fertilized with $80 \mathrm{~kg} \mathrm{ha}^{-1}$ of $\mathrm{P}_{2} \mathrm{O}_{5}$ as single superphosphate. The first nitrogen fertilization was $137 \mathrm{~kg} \mathrm{ha}^{-1}$, and the second was $89 \mathrm{~kg} \mathrm{ha}^{-1} \mathrm{~N}$ in the form of urea.

The evaluation of the decomposition of the vegetal residues was initiated after the cut of the aerial part of the plants. Soon after the cut, samples were taken for the determination of the dry and fresh biomass and the levels of N, P, K, Ca in G. The first method of evaluating the nutrient release of plant residues was carried out by packing $100 \mathrm{~g}$ of fresh material (legume combinations) into bags made with plastic mesh (litterbags) with a mesh opening of $4 \mathrm{~mm}$. The second method to evaluate the nutrient release of plant residues was carried out using a collector commonly used to estimate dry matter production in pastures (Morley, Bennett, \& Clark, 1964), a jig-a detachable accessory, made of wood in the same dimensions of litterbags $(0.40 \times 0.40 \mathrm{~m})$. The litterbags were arranged on the soil surface and the decomposition and nutrient release rates were monitored through collections at $0,30,60,90$ and 120 days after field installation. The template was thrown three times in each experimental plot and the litter was collected at $0,30,60,90$, and 120 in 2014. At each collection date, the remaining litterbags and the template litter were taken to the laboratory and removed the soil particles. After this step, the samples were packed in paper bags and taken to the forced air ventilation oven at $65^{\circ} \mathrm{C}$ until the material reached a constant mass for dry mass determination.

The dried material was processed in a Willey type mill (20 mm sieve aperture). $\mathrm{N}$ analysis was then performed according to the method recommended by Bremner and Mulvaney (1982). P and K were determined from nitric-perchloric digestion (Bataglia, A. M. C. Furlani, Teixeira, P. R. Furlani, \& Gallo, 1983). The determination of $\mathrm{P}$ was made by colorimetry through the formation of the blue color of the phosphate-molybdate complex in the presence of ascorbic acid, and $\mathrm{K}$ by atomic absorption spectrophotometry (EMBRAPA, 1997). The Ca, Mg and $\mathrm{Mn}$ determinations were made by atomic absorption spectrophotometry (Bataglia et al., 1983). The decomposition of residues and nutrient release followed the simple exponential model used by Rezende et al. (1999):

$$
X=X_{0} e-k t
$$

Where: $\mathrm{X}=$ Dry matter amount remaining after a $\mathrm{t}$ period of time; Xo = Initial dry matter amount; $\mathrm{k}=$ decomposition constant; $\mathrm{t}=$ time, in days.

By rearranging the terms of this equation, it is possible to calculate the decomposition constant or value $\mathrm{k}$ :

$$
k=\ln \left(\frac{X}{X_{0}}\right) / t
$$

The half-life time is another important parameter in the evaluation of the decomposition of plant residues, expressing the period of time, in days, necessary for half of the material to decompose, or for half of the nutrients contained in the residues to be released. According to Rezende et al. (1999), it is possible to calculate the half-life time through the equation:

$$
\frac{t_{1}}{2}=\ln (2) / k
$$


The data were submitted to normality tests (Cramer Von-Mises) and homoscedasticity test (Levene), and, assuming these assumptions, were submitted to analysis of variance and the means compared by the Tuckey test $(p>0.05)$ with the InfoStat software (2014).

\section{Results}

The mean values of the initial nutrient contents are shown in Table 1. The litterbags presented high levels of $\mathrm{N}$ and $\mathrm{Ca}$, the combination of $\mathrm{G}+\mathrm{A}$ presented the highest $\mathrm{N}$ content $\left(45.3 \mathrm{~g} \mathrm{~kg}^{-1}\right)$ in relation to the other combinations, and the combination of $\mathrm{L}+\mathrm{S}$ presented the highest levels of $\mathrm{Ca}\left(10.78 \mathrm{~g} \mathrm{~kg}^{-1}\right)$ and $\mathrm{Mg}\left(7.71 \mathrm{~g} \mathrm{~kg}^{-1}\right)$ (Table 1). In initial litter content, the combination of $\mathrm{G}+\mathrm{A}$ and $\mathrm{L}+\mathrm{A}$ presented higher amount of $\mathrm{N}$ and $\mathrm{C}$ (Table $1)$.

Table 1. Average of the initial levels of nutrients contained in the biomass obtained by the methods of litterbags and collecting litter in combinations of different legumes in a system in alleys

\begin{tabular}{|c|c|c|c|c|c|c|c|}
\hline Combined Species in litterbags & $\mathbf{N}$ & $\mathbf{C}$ & $\mathbf{P}$ & $\mathbf{K}$ & $\mathbf{C a}$ & Mg & Mn \\
\hline & \multicolumn{6}{|c|}{ - } & $-\mathrm{mg} \mathrm{kg}^{-1}-$ \\
\hline Leucena + sombreiro & $35.3 b$ & $227.7 \mathrm{c}$ & $1.88 \mathrm{a}$ & $5.76 \mathrm{a}$ & $10.78 \mathrm{a}$ & $4.71 \mathrm{a}$ & $0.87 \mathrm{c}$ \\
\hline Leucena+acacia & $34.9 \mathrm{~b}$ & $553.8 \mathrm{a}$ & $1.76 \mathrm{a}$ & $9.93 b$ & $5.70 \mathrm{~b}$ & $1.84 \mathrm{~b}$ & $1.03 \mathrm{~b}$ \\
\hline Gliricidia+sombreiro & $35.3 b$ & $322.4 \mathrm{c}$ & $0.53 b$ & $8.44 b$ & $6.02 \mathrm{~b}$ & $2.11 \mathrm{~b}$ & $1.24 \mathrm{a}$ \\
\hline Gliricidia+acacia & $45.3 \mathrm{a}$ & $392.4 \mathrm{~b}$ & $0.64 b$ & $4.99 \mathrm{a}$ & $5.95 \mathrm{~b}$ & $1.51 \mathrm{~b}$ & $0.83 \mathrm{c}$ \\
\hline \multirow[t]{2}{*}{ Combined species in litter } & $\mathbf{N}$ & $\mathbf{C}$ & $\mathbf{P}$ & $\mathbf{K}$ & $\mathbf{C a}$ & Mg & Mn \\
\hline & \multicolumn{6}{|c|}{ 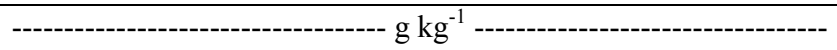 } & $-\mathrm{mg} \mathrm{kg}^{-1}-$ \\
\hline Leucena + sombreiro & $3.7 \mathrm{~b}$ & $503.2 \mathrm{c}$ & $0.62 \mathrm{a}$ & $1.2 \mathrm{~b}$ & $3.9 \mathrm{a}$ & $0.4 \mathrm{a}$ & $0.9 \mathrm{~b}$ \\
\hline Leucena+acacia & $4.5 \mathrm{a}$ & $657.0 \mathrm{~b}$ & $0.26 \mathrm{c}$ & $2.1 \mathrm{a}$ & $1.4 \mathrm{c}$ & $0.3 \mathrm{a}$ & $0.7 \mathrm{c}$ \\
\hline Gliricidia+sombreiro & $3.6 \mathrm{~b}$ & $518.4 \mathrm{c}$ & $0.70 \mathrm{a}$ & $2.3 \mathrm{a}$ & $2.1 \mathrm{~b}$ & $0.2 \mathrm{a}$ & $0.8 \mathrm{~b}$ \\
\hline Gliricidia+acacia & $4.7 \mathrm{a}$ & $855.4 \mathrm{a}$ & $0.37 b$ & $1.3 b$ & $1.2 \mathrm{c}$ & $0.3 \mathrm{a}$ & $1.2 \mathrm{a}$ \\
\hline
\end{tabular}

Note. Values represent averages of 8 repetitions; averages followed by equal letters in the columns do not differ by Tukey's test $(\mathrm{p}>0.05)$.

The $\mathrm{C} / \mathrm{N}$ ratio in the first and second collection ( 0 and 30$)$ was higher for the litter. In the third collection (60 days) the $\mathrm{C} / \mathrm{N}$ ratio was higher for litterbags, remaining larger until the last collection at 120 days (Table 2).

Table 2. Average of $\mathrm{C} / \mathrm{N}$ ratio of tree biomass combinations of different legumes and litter formed in a system in alleys, for 120 days

\begin{tabular}{llllll}
\hline Combined species in litter & $\mathbf{0}$ & $\mathbf{3 0}$ & $\mathbf{6 0}$ & $\mathbf{9 0}$ & $\mathbf{1 2 0}$ \\
\hline Leucena+sombreiro & $37.0 \mathrm{~b}$ & $22.3 \mathrm{~b}$ & $11.0 \mathrm{a}$ & $7.8 \mathrm{a}$ & $6.8 \mathrm{a}$ \\
Leucena+acacia & $32.5 \mathrm{c}$ & $27.5 \mathrm{a}$ & $9.5 \mathrm{a}$ & $5.3 \mathrm{~b}$ & $5.0 \mathrm{~b}$ \\
Gliricidia+sombreiro & $39.1 \mathrm{a}$ & $21.2 \mathrm{~b}$ & $8.0 \mathrm{~b}$ & $5.0 \mathrm{~b}$ & $6.8 \mathrm{a}$ \\
Gliricidia+acacia & $39.4 \mathrm{a}$ & $17.0 \mathrm{c}$ & $7.5 \mathrm{~b}$ & $6.6 \mathrm{a}$ & $6.3 \mathrm{a}$ \\
\hline Combined species in litterbags & $\mathbf{0}$ & $\mathbf{3 0}$ & $\mathbf{6 0}$ & $\mathbf{9 0}$ & $\mathbf{1 2 0}$ \\
\hline Leucena+sombreiro & $6.4 \mathrm{c}$ & $8.9 \mathrm{a}$ & $24.5 \mathrm{a}$ & $41.8 \mathrm{~b}$ & $82.6 \mathrm{~b}$ \\
Leucena+acacia & $15.8 \mathrm{a}$ & $9.3 \mathrm{a}$ & $24.3 \mathrm{a}$ & $23.2 \mathrm{c}$ & $84.9 \mathrm{~b}$ \\
Gliricidia+sombreiro & $9.1 \mathrm{~b}$ & $8.7 \mathrm{a}$ & $24.5 \mathrm{a}$ & $54.8 \mathrm{a}$ & $107.6 \mathrm{a}$ \\
Gliricidia+acacia & $8.6 \mathrm{~b}$ & $8.2 \mathrm{a}$ & $23.9 \mathrm{a}$ & $39.8 \mathrm{~b}$ & $77.6 \mathrm{~b}$
\end{tabular}

Note. Values represent averages of 8 repetitions; averages followed by equal letters in the columns do not differ by Tukey's test $(\mathrm{p}>0.05)$.

The gliricidia+sombreiro and gliricidia+acacia combinations were statistically more rapidly decomposed than the combinations of leucena + sombrero and leucena + acacia (Table 3 ). 
Table 3. Parameters the equation $X=X_{0} e^{-k t}$ adjusted the values of dry matter and dry of half-life time, Chapadinha, MA, Brazil

\begin{tabular}{llcl}
\hline \multirow{2}{*}{ Combined species } & \multicolumn{3}{c}{ Decomposition Equation Parameters } \\
\cline { 2 - 4 } & $\mathbf{k}\left(\right.$ days $\left.^{-\mathbf{1}}\right)$ & $\left.\mathbf{t}_{\mathbf{1} 2} \mathbf{( d a y s}\right)$ & $\mathbf{r}^{\mathbf{2}}$ \\
\hline Leucena+sombreiro & $0.005 \mathrm{c}$ & $152 \mathrm{a}$ & 0.94 \\
Leucena+acacia & $0.007 \mathrm{c}$ & $120 \mathrm{~b}$ & 0.98 \\
Gliricidia+sombreiro & $0.017 \mathrm{a}$ & $40 \mathrm{~d}$ & 0.97 \\
Gliricidia+acacia & $0.012 \mathrm{~b}$ & $61 \mathrm{c}$ & 0.98 \\
\hline
\end{tabular}

Note. $\mathrm{t}_{1 / 2}=$ half-life time.

In relation to the half-life and nutrient release, $\mathrm{N}$ and $\mathrm{P}$ present in the litterbag were released faster in the environment when compared to the release that normally occurs in litter deposited in the soil. The mean difference in $\mathrm{N}$ half-life was 51.25 days and for $\mathrm{P}$ was $19.5 \mathrm{~K}, \mathrm{Ca}, \mathrm{Mg}$ and $\mathrm{Mn}$ presented longer half-life for the litterbags method, with a mean difference of $17.5,16.5,44.5$ and 12 days respectively. On the other hand to the combination of legume species, $\mathrm{L}+\mathrm{S}$ presented longer half-life for $\mathrm{N}$, this was observed in the two collection methods. for the nutrient $\mathrm{P}$, the longer half-life was observed in the $\mathrm{L}+\mathrm{A}$ treatment also for the two collection methods. For K, G+A presented longer half-life in the litterbags method, while in the second method the longer half-life was observed in the $\mathrm{L}+\mathrm{S}$ treatment. The $\mathrm{G}+\mathrm{S}$ treatment showed the longest half-life for $\mathrm{Ca}$, using the litterbag method. In the direct collection method, the $\mathrm{Ca}$ did not show large differences. $\mathrm{Mg}$ was higher for the $\mathrm{L}+\mathrm{A}$ treatment and $\mathrm{G}+\mathrm{S}$ in the litterbag method and the direct collection method was higher for the $\mathrm{G}+\mathrm{A}$ treatments. The $\mathrm{Mn}$ presented higher in the treatment $\mathrm{L}+\mathrm{A}$ and $\mathrm{L}+\mathrm{S}$ for litterbag and direct collection, respectively.

Table 4. Parameters of the equation $X=X_{0} e^{-k t}$ adjusted the values of $\mathrm{N}, \mathrm{P}, \mathrm{K}, \mathrm{Ca}$ and $\mathrm{Mg}$ and half-life time of four combinations of different legumes in the method of litterbags in Chapadinha, Maranhão, Brazil

\begin{tabular}{|c|c|c|c|c|}
\hline Combined species & Nutrient & $k\left(\right.$ days $\left.^{-1}\right)$ & $t_{1 / 2}$ (days) & $\mathbf{r}^{2}$ \\
\hline Leucena+sombreiro & $\mathrm{N}$ & 0.024 & 31 & 0.99 \\
\hline Leucena+acacia & $\mathrm{N}$ & 0.023 & 30 & 0.98 \\
\hline Gliricidia+sombreiro & $\mathrm{N}$ & 0.020 & 27 & 0.98 \\
\hline Gliricidia+acacia & $\mathrm{N}$ & 0.029 & 24 & 0.95 \\
\hline Leucena + sombreiro & $P$ & 0.019 & 43 & 0.84 \\
\hline Leucena+acacia & $\mathrm{P}$ & 0.015 & 63 & 0.95 \\
\hline Gliricidia+sombreiro & $P$ & 0.062 & 15 & 0.91 \\
\hline Gliricidia+acacia & $P$ & 0.016 & 49 & 0.54 \\
\hline Leucena + sombreiro & $\mathrm{K}$ & 0.016 & 43 & 0.57 \\
\hline Leucena+acacia & $\mathrm{K}$ & 0.02 & 42 & 0.95 \\
\hline Gliricidia+sombreiro & $\mathrm{K}$ & 0.07 & 12 & 0.87 \\
\hline Gliricidia+acacia & $\mathrm{K}$ & 0.014 & 49 & ND \\
\hline Leucena + sombreiro & $\mathrm{Ca}$ & 0.024 & 30 & 0.90 \\
\hline Leucena+acacia & $\mathrm{Ca}$ & 0.015 & 49 & 0.65 \\
\hline Gliricidia + sombreiro & $\mathrm{Ca}$ & 0.016 & 68 & 0.98 \\
\hline Gliricidia+acacia & $\mathrm{Ca}$ & 0.013 & 65 & 0.64 \\
\hline Leucena + sombreiro & $\mathrm{Mg}$ & 0.01 & 63 & 0.93 \\
\hline Leucena+acacia & $\mathrm{Mg}$ & 0.01 & 67 & 0.85 \\
\hline Gliricidia+sombreiro & $\mathrm{Mg}$ & 0.003 & 66 & ND \\
\hline Gliricidia+acacia & $\mathrm{Mg}$ & 0.004 & 54 & ND \\
\hline Leucena + sombreiro & $\mathrm{Mn}$ & 0.006 & 75 & 0.72 \\
\hline Leucena+acacia & $\mathrm{Mn}$ & 0.001 & 85 & 0.76 \\
\hline Gliricidia+sombreiro & Mn & 0.02 & 35 & 0.78 \\
\hline Gliricidia+acacia & $\mathrm{Mn}$ & 0.03 & 41 & 0.77 \\
\hline
\end{tabular}

Note. $\mathrm{t}_{1 / 2}=$ half-life time. ${ }^{2} \mathrm{ND}=$ data not fitted to the simple exponential model according to regression analysis $(\mathrm{p}<0.05)$. 
Table 5. Parameters of the equation $X=X_{0} e^{-k t}$ adjusted the values of $\mathrm{N}, \mathrm{P}, \mathrm{K}, \mathrm{Ca}$ and $\mathrm{Mg}$ and half-life time of litter consists of four combinations of different leguminous trees, Chapadinha, Maranhão, Brazil

\begin{tabular}{|c|c|c|c|c|}
\hline Combined species & Nutrient & $k\left(\right.$ days $\left.^{-1}\right)$ & $t_{1 / 2}$ (days) & $\mathbf{r}^{2}$ \\
\hline Leucena+sombreiro & $\mathrm{N}$ & 0.02 & 112 & 0.72 \\
\hline Leucena+acacia & $\mathrm{N}$ & 0.03 & 73 & 0.59 \\
\hline Gliricidia+sombreiro & $\mathrm{N}$ & 0.03 & 84 & 0.55 \\
\hline Gliricidia+acacia & $\mathrm{N}$ & 0.03 & 48 & 0.50 \\
\hline Leucena+sombreiro & $\mathrm{P}$ & 0.02 & 64 & 0.73 \\
\hline Leucena+acacia & $\mathrm{P}$ & 0.02 & 74 & 0.83 \\
\hline Gliricidia+sombreiro & $\mathrm{P}$ & 0.01 & 40 & ND \\
\hline Gliricidia+acacia & $\mathrm{P}$ & 0.02 & 70 & 0.57 \\
\hline Leucena+sombreiro & $\mathrm{K}$ & 0.003 & 27 & 0.63 \\
\hline Leucena+acacia & $\mathrm{K}$ & 0.004 & 26 & 0.75 \\
\hline Gliricidia+sombreiro & $\mathrm{K}$ & 0.009 & 25 & 0.94 \\
\hline Gliricidia+acacia & $\mathrm{K}$ & 0.004 & 24 & 0.98 \\
\hline Leucena+sombreiro & $\mathrm{Ca}$ & 0.01 & 38 & 0.70 \\
\hline Leucena+acacia & $\mathrm{Ca}$ & 0.006 & 37 & 0.90 \\
\hline Gliricidia+sombreiro & $\mathrm{Ca}$ & 0.01 & 36 & 0.93 \\
\hline Gliricidia+acacia & $\mathrm{Ca}$ & 0.01 & 35 & ND \\
\hline Leucena + sombreiro & $\mathrm{Mg}$ & 0.006 & 11 & 0.83 \\
\hline Leucena+acacia & $\mathrm{Mg}$ & 0.007 & 13 & 0.62 \\
\hline Gliricidia+sombreiro & $\mathrm{Mg}$ & 0.008 & 23 & 0.58 \\
\hline Gliricidia+acacia & $\mathrm{Mg}$ & 0.008 & 25 & ND \\
\hline Leucena + sombreiro & $\mathrm{Mn}$ & 0.001 & 71 & 0.68 \\
\hline Leucena+acacia & $\mathrm{Mn}$ & 0.0002 & 66 & 0.61 \\
\hline Gliricidia+sombreiro & $\mathrm{Mn}$ & 0.0003 & 53 & 0.72 \\
\hline Gliricidia+acacia & $\mathrm{Mn}$ & 0.0003 & 34 & 0.78 \\
\hline
\end{tabular}

Note. $\mathrm{t}_{1 / 2}=$ half-life time. ${ }^{2} \mathrm{ND}=$ data not fitted to the simple exponential model according to regression analysis $(\mathrm{p}<0.05)$.

\section{Discussion}

The nutrients present in the biomass of the litterbags at the beginning of the experiment present higher levels of nutrients when compared to the litter nutritional contents. This was due to the biomass of litter that was already in the process of decomposition for a year in the field, without the contribution of new tree biomass and the biomass present in litterbag was fresh biomass. In litterbags the combination of $\mathrm{G}+\mathrm{A}$ showed the highest $\mathrm{N}$ content in relation to the other combinations, Moura et al. (2009), and Schwendener, Lehmann, Carmargo, Luizao, and Fernandes (2005) also found similar values for $\mathrm{N}$ content in combinations that used gliricidia as biomass for ground cover.

Nitrogen is one of the main limiting factors of decomposition. It determines microbial activity and mineralization influences of organic C (Currie \& Aber, 1997). The rate of mineralization of an organic substrate can usually be predicted by its $\mathrm{C} / \mathrm{N}$ ratio or the $\mathrm{N}$ content. When the $\mathrm{C} / \mathrm{N}$ ratio is less than 20 or the $\mathrm{N}$ content of more than $2.5 \%, \mathrm{~N}$ is mineralized and the decomposition of the residues is rapid. In contrast, $\mathrm{N}$ tends to be immobilized when the $\mathrm{C} / \mathrm{N}$ ratio is greater than 20 and the decomposition of the residues is delayed (Currie \& Aber, 1997).

This study shows that the $\mathrm{C} / \mathrm{N}$ ratio of the two collection methods varied over the experimental period (120 days). Differences were observed in the $\mathrm{C} / \mathrm{N}$ ratio between residues that were in litterbags and residues collected directly in the litter (Table 2). At day 0 the differences found between the two methods of collection were already expected, since the litter was in the process of decomposition for a year without addition of biomass. However, after 30 days, the $\mathrm{C} / \mathrm{N}$ ratio remained low for the residues analyzed in the litterbags, which did not correspond to the values for the litter. After 60 days, the opposite effect was observed, where the $\mathrm{C} / \mathrm{N}$ ratio decreases to the litter and begins to increase to the residuals in the litterbags. This behavior was observed up to 120 days, which implies that this method is providing a different environment from the litter, where it would be overestimating the $\mathrm{C} / \mathrm{N}$ ratio and retarding the decomposition. 
It should be noted that the nutritional requirements of a crop intercropped with tree legumes through biomass input do not depend exclusively on the quantity and content of the nutrients contained in the material, but mainly on the transfer efficiency of these nutrients (Ferraz Júnior, 2004), which is linked to the low $\mathrm{C} / \mathrm{N}$ ratio. The data obtained in this experiment leads to the conclusion that the mixture of the new biomass contribution with the existing litter modifies the $\mathrm{C} / \mathrm{N}$ ratio, so the results for this relation obtained by the litterbags method are underestimating the real values up to 30 days and overestimating after 60 days in the field (Table 2).

Research has shown that there are a number of factors that influence the decomposition process, such as environmental factors, soil organisms, organic matter quality and soil management, which are also crucial in this process (Ferraz Júnior, 2004; Fortes, Balieiro, \& Franco, 2004).

The difference of decomposition between $\mathrm{G}+\mathrm{A}, \mathrm{G}+\mathrm{S}$ and $\mathrm{L}+\mathrm{S}, \mathrm{L}+\mathrm{A}$ may be due to the environment in which the material to be decomposed is located. Berg and McClaugherty (2008) suggested that greater moisture can cause a lack of oxygen for decomposers, for example white rot fungi, uses oxygen-dependent peroxidases. Even in an environment, not completely anaerobic, such as litterbags, the least amount of oxygen to litter can have clear effects. A general effect is slower decomposition. In addition, an incomplete metabolism may cause the formation of organic acids, for example, acetic acid, not only generating a lower $\mathrm{pH}$ but also having an antimicrobial effect (Berg \& McClaugherty, 2008).

Another possible explanation for the greater decomposition of these treatments $(\mathrm{L}+\mathrm{S}$ and $\mathrm{L}+\mathrm{A})$ may be the high carbon content (Table 1) in the litter of these treatments. The presence of $\mathrm{C}$ in litter may have induced the production of a greater variety of enzymes, which in turn may have increased the ability of microorganisms to decompose different types of substrates (Chapman, Newman, Hart, Schweitzer, \& Koch, 2013).

However, the $\mathrm{L}+\mathrm{A}$ combination also presented high levels of $\mathrm{C}$ in the litter. In slower decomposition combinations, decomposers could be limited by the quality of the source of $\mathrm{C}$ (for example, lignin ratio), by the amount of $\mathrm{N}$ or by its interaction (Hoorens, Coomes, \& Rien, 2010).

The greatest difference between the half-life times $(\mathrm{G}+\mathrm{A}=61$ days and $\mathrm{L}+\mathrm{S}=152$ days $)$ also showed significant differences in N contents (Table 1), both litterbags and litter. Similar results were found by Harguindeguy, Blundo, Gurvich, Dias, and Cuevas (2008), where the fastest rate of decomposition was found in combinations with higher nitrogen content and greater heterogeneity in non-labile compounds. Bonanomi et al. (2016) also showed that the litter mass loss and $\mathrm{N}$ dynamics are hierarchically regulated by the internal litter $\mathrm{N}$ content, the soil $\mathrm{N}$ availability and the litter lignin content.

In the combination of $\mathrm{G}+\mathrm{S}$, the resources may have been more easily degradable and available for decomposers, leading to an overall high availability of nutrients in the combination and allowing the transfer of nutrients to the low quality litter, thus enhancing decomposition. Other mechanisms, such as dilution of secondary compounds, improvement of microenvironmental conditions, or the effects of the specific compound, should not be discarded, however our experimental design does not allow us to draw conclusions along these lines.

In another aspect, this combination $(\mathrm{G}+\mathrm{S})$ was the one with the highest levels of $\mathrm{C}$ in the two collection methods. If the decomposers are limited by the amount of $\mathrm{C}$ present in rapidly decomposed species, then when a higher source of $\mathrm{C}$, or a different source of $\mathrm{C}$ is added, decomposition can be accelerated (Hoorens et al., 2010; Berglund, Agren, \& Ekblad, 2013).

From the values $\mathrm{k}$, the following order of release was established for the litterbags method: $\mathrm{P}>\mathrm{N}>\mathrm{K}>\mathrm{Ca}>$ $\mathrm{Mn}>\mathrm{Mg}$, and for the method of collecting the litter the following order of release was established: $\mathrm{N}>\mathrm{P}>\mathrm{Ca}>$ $\mathrm{Mg}>\mathrm{K}>\mathrm{Mn}$. Leaf litter represents the largest input of nutrients to soils in most ecosystems, and the differences in the levels of some nutrients ( $\mathrm{P}, \mathrm{K}, \mathrm{Na}, \mathrm{Mg}$, and $\mathrm{Mn}$ ) between plant species may reflect species-specific strategies for resource use or acquisition (Fujii, Makita, Mori, \& Takeda, 2016).

The longest half-life found for $\mathrm{N}$ was the combination of $\mathrm{L}+\mathrm{S}$, for the two collection methods, however the difference between them is great (112 days for litter residues and 31 days for litterbag residues). In this combination, which presented slow decomposition and slow release of $\mathrm{N}$ in the litter, the decomposers could be limited by the quality of the source of $\mathrm{C}$ (for example, lignin ratio), by the amount of total $\mathrm{N}$ or by their interaction (Hoorens et al., 2010).

Another possible explanation is that the $\mathrm{N}$ content in combinations with high initial lignin content suggests that antagonistic effects could be related to the formation of recalcitrant $\mathrm{N}$-lignin complexes in these combinations (Berg \& McClaugherty, 2008). The initial lignin content found for this combination is $\left(214 \mathrm{Mg} \mathrm{ha}^{-1}\right)$ (Moura et al., 2009), almost double the ideal value, which is usually the consequence of this combination to retard decomposition and nutrient release (M. M. Rahman, Tsukamoto, Md. M. Rahman, Yoneyama, \& Mostafa, 2013). 
The Ca contents of the gliricidia treatments were released more slowly than the treatments with leucena, contrary situation observed in the $\mathrm{K}$ contents. However, when comparing the half-life times of the two types of collection it was observed that in litterbags the release of calcium was approximately 50\% slower than in the litter (Tables 4 and 5). A possible explanation for this difference is that in the litterbags there was a higher concentration of fungal colonies compared to the litter environment, what was observed in the field is that litterbags even with a suitable mesh opening provide a higher moisture content compared to litter. This may have favored a longer period of $\mathrm{Ca}$ accumulation, which is due to the absorption of this element into fungal hyphae as documented by Cromack et al. (1978) and Swift, Russell-Smith, and Perfect (1981).

Berg (2014) reported that groups of microorganisms that cause white rot and brown rot can be related to $\mathrm{N}$ and Mn contents. Fungi that cause white rot have the ability to completely degrade lignin and lignified tissues, whereas microorganisms that cause brown-colored rot are limited to breaking the side chain of the aromatic nucleus of the lignin molecule (Hatakka, 2001). Our results, observed in the field, showed higher amounts of white rot in the combinations of gliricidia, whereas brown rot was observed in greater amounts in the combinations with leucena.

This result is compatible with the $\mathrm{N}$ and $\mathrm{Mn}$ contents found in this study. Combinations with gliricidia had higher levels of $\mathrm{N}$ and Mn. Berg (2014) reports that the litter in which white rot fungi dominates, degradation would remain unimpeded, especially at low $\mathrm{N}$ concentrations, which was also observed in our study, where combinations with gliricidia showed faster decomposition than combinations with leucaena. According to Hatakka (2001) almost all fungi of white rot have Mn peroxide (MnP) and their activity would be related to the availability of Mn. In contrast, no brown rot fungus was found with MnP.

Observing the results of the $\mathrm{N}$ and $\mathrm{Mn}$ contents of this study, we can see that litter samples with a high concentration of $\mathrm{Mn}(\mathrm{G}+\mathrm{A}$ and $\mathrm{G}+\mathrm{S})$ may favor the invasion of white rot fungus instead of rot fungi brown. Thus, the higher the concentration of Mn, the better the support for the growth of fungi of white rot, which in turn would support a faster decomposition in the humid tropics. In particular, there is a need to differentiate how the decomposition environment (e.g. soil characteristics, soil fauna, temperature and precipitation) are influencing these effects inside and outside litterbags.

\section{Acknowledgements}

We especially thank the Fundação de Apoio à Pesquisa e ao Desenvolvimento Científico e Tecnológico do Maranhão (FAPEMA) in collaboration with Conselho Nacional de Desenvolvimento Científico e Tecnológico (CNPq), for their financial support.

\section{Conclusions}

It is concluded that the combinations of legume species showed different patterns of nutrient decomposition and release in the two evaluated methods. The litterbags method showed a higher $\mathrm{C} / \mathrm{N}$ ratio at day 30 up to 120 days, which implies that this method is providing a different environment from the litter, where it would be overestimating the $\mathrm{C} / \mathrm{N}$ ratio and retarding the decomposition. The $\mathrm{G}+\mathrm{S}$ and $\mathrm{G}+\mathrm{A}$ combinations were more rapidly decomposed than the combinations of $\mathrm{L}+\mathrm{S}$ and $\mathrm{L}+\mathrm{A}$. The following order of release was established for the litterbags method: $\mathrm{P}>\mathrm{N}>\mathrm{K}>\mathrm{Ca}>\mathrm{Mn}>\mathrm{Mg}$, and for the method of collecting the litter: $\mathrm{N}>\mathrm{P}>\mathrm{Ca}>$ $\mathrm{Mg}>\mathrm{K}>\mathrm{Mn}$.

\section{References}

Andrade, A. G., Caballero, S. S. U., \& Faria, S. M. (1999). Ciclagem de nutrientes em ecossistemas florestais. Brazil, BR: Rio de Janeiro.

Bataglia, O. C., Furlani, A. M. C., Teixeira, J. P. F., Furlani, P. R., \& Gallo, J. R. (1983). Métodos de análise química de plantas. Brazil, BR: Campinas.

Berg, B. (2014) Decomposition patterns for foliar litter e a theory for influencing factors. Soil Biology \& Biochemistry, 78, 222-232. https://doi.org/10.1016/j.soilbio.2014.08.005

Berg, B., \& McClaugherty, C. (2008). Plant litter: decomposition, humus formation, carbon sequestration. Choice Reviews Online, 51, 51-6172. https://doi.org/10.5860/choice.51-6172

Berglund, S. L., Agren, G. I., \& Ekblad, A. (2013). Carbon and nitrogen transfer in leaf litter mixtures. Soil Biology \& Biochemistry, 57, 341-348. https://doi.org/10.1016/j.soilbio.2012.09.015

Bonanomi, G., Cesarano, G., Gaglione, S. A., Ippolito, F., Sarker, T., \& Rao, M. A. (2017). Soil fertility promotes decomposition rate of nutrient poor, but not nutrient rich litter through nitrogen transfer. Plant \& Soil, 412, 397-41. https://doi.org/10.1007/s11104-016-3072-1 
Bremner, J. M., \& Mulvaney, C. S. (1982). Methods of soil Analysis. United States, EU: Madison.

Chapman, S. K., Newman, G. S., Hart, S. C., Schweitzer, J. A., \& Koch, G. W. (2013). Leaf litter mixtures alter microbial community development: Mechanisms for non-additive effects in litter decomposition. PloS One, 8, 6267. https://doi.org/10.1371/journal.pone.0062671

Cromack, K. Jr., Sollins, R. L., Todd, R., Fogel, A. W., Todd, W. M., Fender, M. E., ... Crossley, Jr. (1978). The role of oxalic acid and bicarbonate in calcium cycling by fungi and bacteria: Some possible implications for soil animals. Soil Organisms as Components of Ecosystems, 25, 246-252. https://doi.org/10.1007/ 978-3-642-88448-1_9

Currie, W. S., \& Aber, J. D. (1997). Modeling leaching as a decomposition process in humid montane forests. Ecology, 78, 1844-1860. https://doi.org/10.2307/2266106

EMBRAPA (Empresa Brasileira de Pesquisa Agropecuária). (1997). Manual de métodos de análises de solo. Brasil, RJ: Empresa Brasileira de Pesquisa Agropecuária.

Ferraz Júnior, A. S. L. (2004). Agroambientes de transição entre o trópico úmido e o semi-árido do Brasil. Atributos; Alterações; Uso na Produção. Brasil, BR: São Luís.

Fortes, J. L. O., Balieiro, F. C., \& Franco, A. A. (2004). Agroambientes de transição entre o trópico úmido e o semi-árido do Brasil. Atributos; Alterações; Uso na Produção Familiar. Brasil, BR: São Luís.

Fujii, S., Makita, N., Mori, A. S., \& Takeda, H. (2016). A stronger coordination of litter decomposability between leaves and fine roots for woody species in a warmer region. Trees, 30, 395-404. https://doi.org/10.1007/ s00468-015-1221-4

Harguindeguy, N. P., Blundo, C. M., Gurvich, C. E., Dias, S., \& Cuevas, E. (2008). More than the sum of its parts? Assessing litter heterogeneity effects on the decomposition of litter mixtures through leaf chemistry. Plant and Soil, 151-159. https://doi.org/10.1007/s11104-007-9495-y

Hatakka, A. (2001). Biodegradation of lignin. Lignin, Humic Substances and Coal, 1, 129-180. https://doi.org/ 10.1002/3527600035.bpol1005

Hatakka, A., \& Hammel, K. E. (2010). Fungal biodegradation of lignocelluloses. Industrial Applications, 319-340. https://doi.org/10.1007/978-3-642-11458-8_15

Hobbie, S. E., \& Gough, L. (2004). Litter decomposition in moist acidic and non-acidic tundra with different glacial histories. Oecologia, 140, 113-124. https://doi.org/10.1007/s00442-004-1556-9

Hobbie, S. E., Eddy, W. C., Buyarski, C. R., Carol Adair, E., Ogdahl, M. L., \& Weisenhorn, P. (2012). Response of decomposing litter and its microbial community to multiple forms of nitrogen enrichment. Ecological Monographs, 82, 389-405. http://dx.doi.org/10.1890/11-1600.1

Hoorens, B., Coomes, D., \& Rien, A. (2010). Neighbour identity hardly affects litter mixture effects on decomposition rates of New Zealand forest species. Oecologia, 479-489. https://doi.org/10.1007/ s00442-009-1454-2

Morley, F. H. W., Bennett, D., \& Clark, K. W. (1964). The estimation of pasture yield in large grazing experiments. CSIRO Division of Plant Industry Field Station Record, 3, 43-47. https://doi.org/10.1071/ ea9700694

Moura, E. G., Moura, N. G., Marques, E. S., Pinheiro, K. M., Costa Sobrinho, J. R. S., \& Aguiar, A. C. F. (2009). Evaluating chemical and physical quality indicators for a structurally fragile tropical soil. Soil Use and Management, 25, 368-375. https://doi.org/10.1111/j.1475-2743.2009.00238.x

Rahman, M. M., Tsukamoto, T., Rahman, Md. M., Yoneyama, A., \& Mostafa, K. M. (2013). Lignin and its effects on litter decomposition in forest ecosystems. Chemistry and Ecology, 29, 540-553. https://doi.org/ 10.1080/02757540.2013.790380

Rezende, C., Cantarutti, R., Braga, J., Gomide, J. A., Pereira, J. M., Ferreira, E., ... Boddey, R. M. (1999). Litter deposition and disappearance in Brachiaria pastures in the Atlantic forest region of the South of Bahia, Brazil. Nutrient Cycling in Agroecosystems, 54, 99-112. https://doi.org/10.1023/A:1009797419216

Schwendener, C. M., Lehmann, J., de Carmargo, P. B., Luizao, R. C. C., \& Fernandes, E. C. M. (2005). Nitrogen transfer between high- and low-quality leaves on a nutrient-poor Oxisol determined by $15 \mathrm{~N}$ enrichment. Soil Biology \& Biochemistry, 37, 787-794. https://doi.org/10.1016/j.soilbio.2004.10.011 
Swift, M. J., Russell-Smith, A., \& Perfect, T. J. (1981). Decomposition and mineral-nutrient dynamics of plant litter in a regenerating bush-fallow in sub-humid Tropical Nigeria. Journal of Ecology, 69, 981-995. https://doi.org/10.2307/2259649

\section{Copyrights}

Copyright for this article is retained by the author (s), with first publication rights granted to the journal.

This is an open-access article distributed under the terms and conditions of the Creative Commons Attribution license (http://creativecommons.org/licenses/by/4.0/). 